\title{
Aesthetic Reflexivity in the Global Age
}

\author{
By Luca Serafini*
}

Starting from a contribution of Scott Lash on aesthetic reflexivity, this paper aims to show that this kind of reflexivity can have different meanings and that it is suitable to established a global community. Specifically, aesthetic reflexivity can be seen in the philosophy of deconstruction to maintain the concept of mediation and the reference to a community that Lash seems to exclude. The aesthetic reflexivity implied in deconstructionism is then explained as counteracting the reflexivity that, following Bourdieu and Lash himself, represents the grounds of hermeneutical communities. The latter are based upon pre-reflexive orientations that keep the subject blocked in a structure of power of which it never becomes aware. In contrary to this model, the argument is put forward that the aesthetic reflexivity of deconstructionism implies a different relationship with power in which the subject has the reflexive means to criticize the structures of which it forms a part.

\section{Introduction}

In the contemporary debate regarding conditions of possibility of the existence and activity of a collective - on the theoretical and practical foundation of "we" - the articulation between the community and the practices of reflexivity attached to it (or, according to some, constituting it) is often decisive. The disuse of modern paradigms such as the notion of contract (as well as the types of rationality connected to those models) has steered the debate into three fundamental directions: the liberation of "I" from structure through practices of reflexivity affirming individuality, the mimetic adhesion of "I" to the objectifications that it is immersed in, and introjections of practices and meanings already present within the context of belonging for the "I".

Scott Lash, in his contribution to Reflexive Modernization, ${ }^{1}$ has successfully described these three tendencies, reconnecting each of them to specific authors. The first model, which he defines as "cognitive reflexivity," is considered to be still tied to the Enlightenment project. In this case, in order for the subject to extract itself from the deforming individualization of modernization (consisting of atomism and submission to an often anonymous structure), it reconquers its autonomy through reflexivity, thereby arriving at a more genuine and authentic individualization. According to Lash, Ulrich Beck and Anthony Giddens articulate, this paradigm at its best in other essays

\footnotetext{
* PhD Student, University of Pisa, Italy.

1. Ulrich Beck, Anthony Giddens and Scott Lash, Reflexive Modernization: Politics, Tradition and Aesthetics in the Modern Social Order (Stanford, California: Stanford University Press, 1994).
} 
contained the same anthology. ${ }^{2}$ The second model, defined as "aesthetic reflexivity," postulates a divided "I" lacking in real reflexive mediation and uses allegory to investigate the structures to which the "I" belongs. Lash finds some examples of this reflexivity in Friedrich Nietzsche and Theodor Adorno, although the deconstructionists may bring this thread forward more exhaustively. The third model, the one favoured by Lash, is that of "hermeneutic reflexivity." In this case, the community molds itself according to a set of routines and practices that direct the sharing of signifiers among the subjects. According to Lash, the concept of habitus (as elaborated by Pierre Bourdieu) best explains this third type of community aggregation.

The focus of this paper is on the second type of reflexivity. Omitting Nietzsche and Adorno, the sense will be explored in which deconstructionists may be encompassed in this paradigm. The aim is to explore whether aesthetic reflexivity (especially as presented by the deconstructionists) may contain something different and supplementary at its core with respect to the nonmediated mimesis referred to by Lash. Specifically, the following points will be made: first of all, a form of reflexive mediation exists in deconstructionism and, because of this mediation, "aesthetic reflexivity" is a form of reflexivity. Moreover, the subjectivity prefigured by the deconstructionist aesthetic paradigm does not correspond, as Lash claims, to a "Faustian I" or to an "expressive individualism" but, instead, may serve as the foundational model of "we." Finally, it will be suggested that the relationship with power and the system implied in deconstructionist aesthetic reflexivity is perhaps more critical and aware than the one linked to hermeneutic reflexivity.

\section{Reflexive Mediation}

According to Lash, deconstructionism suffers from a cornering typical of any allegorical thought whose intention is a critique of the universal by nonconceptual means:

I am claiming that analysts in the tradition of allegory from Nietzsche to Benjamin and Adorno, to Derrida, Rorty and Bauman, presume a radical individualism - surely not a utilitarian but an aesthetic individualism: not an individualism of a controlling ego but the individualism of a heterogeneous, contingent desire - which itself is hardly conducive to community. What I am contending is that any understanding of the "we" under the star of aesthetic reflexivity, under the star of such a mimetic critique of the concept, is impossible. ${ }^{3}$

2. Ibid.

3. Ibid., 144. 
The question to be posed here is whether deconstructionism effectively implies a mimetic relationship with the world, and if such a form of mimesis should be thought of exclusively as allegorical thought. If this is the case - as stated by Lash in the above quotation - this position seems to lack the reflexive mediation that is a necessary condition for any philosophy of community that begins, among other things, with a genuinely critical relationship towards the existent. Instead, it can be argued that there is a mimetic relationship in deconstructionism between the "I" and the world that represents a critical reflexivity regarding the latter, as well as an overcoming of the expressive and titanic "I" that is implicated in an "allegorical critique" of the universal.

An author who is not part of the list compiled by Lash but who fully fits the deconstructionist constellation and who elaborates various themes from Jacques Derrida's lesson is Jean-Luc Nancy. The work of Martin Heidegger is central to Nancy's thought, as he tries to retrieve early Heideggerian philosophy - dating back to the 1920s before the so-called Kehre - in service of a philosophy of community. This is the thought of a plural subjectivity, of an "I" that perceives its own alterity within its theoretical constitution as an individual, in line with the theme of the Other that is central to deconstructive thought.

Of most interest, however, is the relationship of this "singular plural" subject with the world. Starting out from Heidegger's paragraph 26 of Being and Time, it must be noted that, for Nancy, the immediacy of Dasein as Beingin-the-world goes hand-in-hand with the immediacy of Being-with (Mitsein). ${ }^{4}$ In Heidegger's text, the two immediacies coincide. Furthermore, Nancy discovers a connection between Being-in-the-world and the One in Heidegger. Inasmuch as Dasein is Being-in-the-world, it is immediately part of (without the possibility of escape) the One that it itself constitutes, along with the other Dasein. This issue is significant, because if the One is viewed as a mere abstraction (as Heidegger undoubtedly does in multiple passages), Being-with can be considered the sharing of signifiers with a community that participates in the same background practices and to which it is possible to oppose the alienating abstractions of Gesellschaft.

By instead re-evaluating the One and making it coincide with Being-inthe-world, the scope of objectifications of which the "I" is part, and from which it is impossible to escape is broadened from the outset. This scope includes not only a community that is close both spatially and culturally, but the entirety of Gesellschaft. Whether Nancy's interpretation is more or less correct with respect to Heidegger's text it is not of immediate interest, since Nancy states that he aims at going beyond Heideggerian philosophy and pushing the latter to its implicit, unexpressed consequences.

4. Martin Heidegger, Joan Stambaugh and Dennis J. Schmidt, Being and Time (Albany: State University of New York Press, 2010) \& Jean-Luc Nancy, "Heidegger's 'Originary Ethics,'" Studies in Practical Philosophy 1, no. 1 (1999). 
Furthermore, this operation of adherence to the One, to the Gesellschaft, on the part of the "I" as Being-in-the-world, has reflexive characteristics in Nancy. A text in which Nancy analyzes paragraphs 54-62 of Being and Time, dedicated to the theme of decision, is a necessary starting point. ${ }^{5}$ Here Heidegger affirms, among other things, that "Resoluteness is an eminent mode of the disclosedness of Dasein." 6 The term Entschlossenheit is translated by Nancy as "openness that decides itself" (ouverture décidante). This is in line with the French translation by Emmanuel Martineau, ${ }^{7}$ who distances himself from the one by Francois Vezin, ${ }^{8}$ which opts instead for "resoluteness" (resolution). In this way, the link between decision and openness implicates possibility as a modality of being of Dasein. In the text under analysis, Nancy also underlines the "worldly" character of decision, namely, the fact that it decides for the world and for nothing else. This "worldly" decision takes place in the One:

Ontical experience takes place right at the "they," and nowhere else. Moreover, there is no "elsewhere": that is the "meaning [Sinn] of Being," and that is exactly what is represented by the major existential characteristics of decision, or by the decided character of existence, or again by the fact that existence is, as such, the decision of existence. ${ }^{9}$

In this passage, the connection between the One and the decision is made explicit: an individual decides for existence and does so directly and immediately within the One. The One should not be viewed as a ground from which one must flee, as an area of inauthentic existence that Dasein could abandon - thanks to a decision understood as the retaking of something found elsewhere in respect to the One. Deciding to exist, in fact, signifies also to decide to exist with others; the inter-subjective experience only has a place in the experience of the One. The particularity of the decision consists here in the fact that Dasein's impropriety has its location in the One, and that this One and Being-in-the-world to which Dasein is delivered from the beginning represent the same thing. In other words, Being-in-the-world signifies immediately Being-with; consequently, the One is also a modality of existence that takes place within Dasein.

If the essence of Dasein's possibility is its indeterminacy and unfinishedness - its existence according to the category of the possible - then it may be affirmed that the decision is made for existence only. This in itself

5. Jean-Luc Nancy, The Birth to Presence (Stanford, California: Stanford University Press, 1993).

6. Heidegger, Stambaugh and Schmidt, Being and Time, 284.

7. Ibid.

8. Ibid.

9. Nancy, The Birth to Presence, 104-105. 
implies indeterminacy and incompleteness in its turn. But deciding to exist does not mean anything more than deciding to be what Dasein always and already is. Dasein exists according to the modality of openness, already implicit in the concept of Being-in-the-world; there is no possibility for thinking of it differently. Decision is the necessary condition of openness. The conclusion is that the decision is a decision to keep openness open, to make Dasein be, starting from that which it is from the beginning, insomuch as it is Being-in-the-world. What is being described, therefore, is not mimetic adhesion and a-reflexivity to the world. While it is true that the "I" is immediately Being-in-the-world and Being-with-others, it decides knowingly to maintain this state. It does so instead of closing itself in a subjectivity that, through a different form of reflexivity (in this case we can define it as a cognitive one), asserts itself outside of the structure.

Nancy thus elaborates an immediacy of the "I"'s relationship with the world and with others that has a fully reflexive character - although a reflexivity that is not cognitive (an "I" that frees itself from the structure) but rather aesthetic (an "I" that adheres to the structure of which it is part). To decide to exist signifies deciding to keep open this original condition of coexistence, without abstracting the "I" from the objectifications that constitute it and to which it itself contributes to forming. It is a reflexivity that maintains a mimetic adhesion of the "I" to the world without abstracting it to its zeropoint. Nevertheless, it remains reflexivity and, as we will demonstrate, a reflexivity that is critical of the world to which it adheres. As has been shown, here the immediacy of the relationship "I-world" is only ostensible.

Still focusing on the relationship between Nancy and Heidegger, it is possible to extend the discourse on reflexivity to the analysis of a structure that has a direct effect on this issue: consciousness. It should be noted that in Nancy's view the reflexive decision to maintain Being-with while not confining oneself in a substantial subjectivity comes from Heidegger's analysis of the theme of consciousness as a "call" in paragraphs 55-57 of Being and Time. Heidegger expresses himself in these terms:

The call is precisely something that we ourselves have neither planned, nor prepared for, nor willfully brought about. "It" calls, against our expectations and even against our will. On the other hand, the call without doubt does not come from someone else who is with me in the world. The call comes from me, and yet over me. [...] The fact that the call is not explicitly brought about by me, but rather, "it" calls, does not justify looking for the caller in a being unlike Dasein. ${ }^{10}$

10. Heidegger, Stambaugh and Schmidt, Being and Time, 265. 
Nancy elucidates the theme of the call in an excerpt from a lecture during a conference dedicated to Jacques Derrida and his End of Man, ${ }^{11}$ an analysis exploring the relationship between Heidegger and Kant.

Nancy's inspiration comes from Derrida's famous analysis of the autonomy of the "I" in his Pure Self-constitution in Edmund Husserl. ${ }^{12}$ Summarizing briefly, Husserl's thesis is that recognizing the fictitious character of the "you" within the "I" that turns to itself allows us to look at the interior monologue of consciousness as a sort of false language.

Pure consciousness, therefore, may not express itself except in silence; or better, the formation of the ego may not come about except in the silence of pure consciousness. ${ }^{13}$ In opposition to this thesis, Derrida locates in Archi-writing a construction of meaning or sense that implies the presence of the other from the very beginning. ${ }^{14}$ Furthermore, according to Derrida, ethics play a role in Archiwriting. In this sense, the inner voice of consciousness that expresses itself as moral consciousness (the Gewissen in which and from which we hear "You have done wrong") is not a silent sermonizing because both the "you" and the "wrong" intervene to determine the origin of meaning for the "I".

This same subjectivity thus observes moral necessity in its self-constitution, the presence of the other and, as a consequence, its own original finitude. This pure injunction of moral consciousness easily becomes a listening to alterity. The "you must" inserts itself in the constitution of meaning for the "I" from the beginning and thus outlines the presence of the other. This is why Nancy may link Kant's categorical imperative, understood as "pure practical reason" and therefore preceding experience, to the phenomenon of the "voice" of consciousness:

Admittedly, nothing resembles a voice, the voice of conscience, the voice of a Bewußtsein as Gewissen, more than this imperative which, for Kant, is to be found everywhere and in everyone, and which is heard prior to all moral choices. Although Kant does not always speak of it as a voice (at any rate, not in an emphatic way in the major texts on practical reason),

11. Jacques Derrida, The Ends of Man, in Margins of philosophy (Chicago: The University of Chicago Press, 1984).

12. Jacques Derrida, Voice and Phenomenon. Introduction to the Problem of the Sign in Husserl's Phenomenology (Northwestern University Press, 2011).

13. Edmund Husserl, Logical Investigations, trans. J.N. Findlay (London: Routledge 1973).

14. The argument was initially outlined by Derrida (Jacques Derrida, Edmund Husserl's "Origin of Geometry" (University of Nebraska Press, 1989)). The topic will be then organically expanded by Derrida in two texts: 1. L'écriture et la difference, Seuil, Paris 1967. English version: Writing and Difference, Routledge \& Kegan Paul Ltd, 1978. 2. De la grammatologie, Editions de Minuit, Paris 1967. English version: Of Grammatology, John Hopkins University Press, 1998. 
one can say that "the moral law within me" is the absolute voice of absolute consciousness. ${ }^{15}$

Pure practical reason is, therefore, the voice of consciousness that demands difference before content-based obligation. It is worthwhile observing that this operation is entirely reflexive, since "I", considering itself as a finite being, tries in practice to reconstitute the conditions that constitute it as an "I". In other words, if the subject is originally inhabited by an alterity, consciousness understood as a call returns it to the necessity of conserving this alterity and inscribing it in the praxis. Without this reflexive operation, the risk for the subject would be to disown its immediate relationship with the other.

\section{The Relationship with Structure and Power}

To understand the systemic consequences of different types of reflexivity, the best starting place is, once again, Heidegger. In the model proposed by Lash, there is a reference to Being and Time in the sharing of signifiers and practices that are common on the part of a historically situated community. In paragraphs 73-74, Heidegger speaks of Dasein absorbed in pre-reflexive practices, whether with equipment (Zeuge) or other finite human beings. Similarly, the Heideggerian concepts of "preoccupation" (besorgen) for things, and "solicitude" (Fürsorgen) for other human beings, reveal a situated and positioned structure of this community, comprised of equipment and Dasein that are valued and cared for. It differentiates itself, according to Lash, by this simple "caringness" (Sorge) that pertains to the relationship of Dasein with itself and in the alienation of its Being-toward-death. When Heidegger speaks of besorgen and Fürsorgen, he is referring to a pre-reflexive distribution of signifiers and common practices among individuals who share these same signifiers and these same practices, according to the model of hermeneutical community proposed by Lash.

At this point, it is not a question of establishing which interpretation of Heideggerian philosophy is the most correct, since both may be valid. Instead, it is a matter of understanding the implications of the two models with respect to the critical and reflexive relationship between subject and structure. To this end, however, it is necessary to take an additional step, one already taken by Lash in referring to Pierre Bourdieu's theorization of a reflexivity that leads to a hermeneutical community. In his most famous work, ${ }^{16}$ Bourdieu connects

15. Lacoue-Labarthe, Philippe, Jean-Luc Nancy, and Simon Sparks, Retreating the Political (London: Routledge, 1997), 43.

16. Pierre Bourdieu, Distinction: A Social Critique of the Judgement of Taste (Cambridge, Massachusetts: Harvard University Press, 1984). 
individual practices to predispositions - to schemata that the individual possesses pre-reflexively and in relation to their class affiliation. According to Lash, it is necessary:

to begin with Bourdieu's idea of reflexivity. In his recent Invitation to Reflexive Sociology Bourdieu speaks of reflexivity in terms of the systematic uncovering of the unthought categories which themselves are

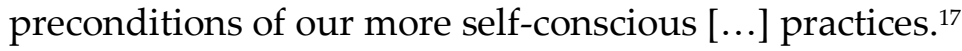

The pre-reflexive of unthought categories refers to predispositions, orientations, routine practices and background activities. The single practice is associated to the pre-reflexive predisposition that the individual possesses in relation to the whole of his affiliations: a totality that, thanks to a historic substratum, modulates the orientations of the praxis of this same individual.

The objective is thus to understand the concrete space of a reflexive critique of practices in Bourdieu's model, and then compare this relationship of subject and structure to the one elaborated in the paradigm of deconstructive aesthetic reflexivity. In order to do so, it would be best to begin as Bourdieu does in Distinction, where he returns to the concept of habitus:

To do this, one must return to the practice-unifying and practice-generating principle, i.e., class habitus, the internalized form of class condition and of the conditionings it entail. One must therefore construct the objective class, the set of agents who are placed in homogeneous conditions of existence imposing homogeneous conditionings and producing homogeneous systems of dispositions capable of generating similar practices; and who possess a set of common properties, objectified properties, sometimes legally guaranteed (as possession of goods and power) or properties embodied as class habitus. $^{18}$

Both the legal guarantee and the "forced" character of the acquisition of these affiliations imposed by class conditions render the totality of practices suspicious from the perspective of individual freedom - if by the latter term one means an aware and reflexive choice of adhering to those same practices. Bourdieu's Distinction seems to describe a mechanism of introjection of class affiliation on the subject's part that hardly leaves any chance of exiting from historically produced and situated universals that constitute the background practices and the schemata of any particular class. For this reason Bourdieu may affirm that:

17. Beck, Giddens and Lash, Reflexive Modernization: Politics, Tradition ..., 154.

18. Bourdieu, Distinction: A Social Critique ..., 101. 
The habitus apprehends differences between conditions, which it grasps in the form of differences between classified, classifying practices (products of other habitus), in accordance with principles of differentiation which, being themselves the product of these differences, are objectively attuned to them and therefore tend to perceive them as natural. ${ }^{19}$

The introjection consists precisely in perceiving as natural those status differences that make themselves objective through practices that in turn develop into a pre-reflexive manner, since they are conditioned through the context of belonging. But the fundamental point, according to Bourdieu, is that the introjection of the practices and the status connected to them could not take place without the basic guidance of a power mechanism whose goal is the maintenance of structures of domination and of a precise social hierarchy:

Adapting to a dominated position implies a form of acceptance of domination. The effects of political mobilization itself do not easily counterbalance the effects of the inevitable dependence of self-esteem on occupational status and income, signs of social value preciously legitimated by the sanctions of the educational market. It would be to enumerate the features of the life-style of the dominated classes which, through the sense of incompetence, failure or cultural unworthiness, imply a form of recognition of the dominant values. ${ }^{20}$

The existence of this "directing class," which stands behind the maintenance of this system of differentiation through a variety of background practices, is evident in Bourdieu's work. It seems, therefore, that predispositions, pre-reflexive orientations, schemata and background practices represent for Bourdieu things that tend to crystallize the social order, representing it as it is, in order to maintain its composition. The risk of a hermeneutic reflexivity understood in this way is in compliance with structures and significant practices to which it belongs, regardless of their value. Lash sustains that in hermeneutic reflexivity "Truth [...] becomes evident through shared practices."21 Nevertheless, the question remains whether this truth is not created ad hoc for the maintenance of pre-existing structure, generating a mechanism of introjections that leads the dominated to perceive the qualities assigned to them by the system as natural.

A rather different relationship with structure becomes evident from the point of view of aesthetic reflexivity. It is true that the subject adheres to the objectifications of which it is part. This is inevitable as long as the "I" is considered immediately in relation with others (whom in any case represent another

19. Ibid., 172.

20. Ibid., 386.

21. Beck, Giddens and Lash, Reflexive Modernization: Politics, Tradition ..., 156. 
"objective" context into which the "I" is inserted), but also with the world. As noted earlier, the subject is immediately Being-in-the-world; it is unthinkable that it would distance itself from the objectifications that constitute it and that it contributes to forming. Indeed, if the subject aimed for a reflexive separation from its context, the "I" would not recognize its constitutively relational nature and would operate within a false relationship with the world in general.

However, it is also true that the relationship of the subject to its objectification, while necessary, is not for this reason uncritical. The reason for this, as noted earlier, is not only because the "I" reflects on its not being able to project itself outside these objectifications, but also because it is constantly aware of its being able to modify them. Aesthetic reflexivity, therefore, puts structure at stake without claiming its ability to exit from structure. Starting from a cosmopolitan perspective, deconstructionists do not reject the possibility that a certain global Being-in-community is objectified in such a way that a particular interest - a power - dominates, obscuring the cum of the original sharing. Such domination might take the form, for example, of an economic power proper to a kind of capitalism that appropriates the global dimension and turns individuals into lifeless cells. Individuals are made into atoms that lack relationships, thus becoming victims of a structure that operates at a level above them, taking advantage of their passivity and atomization.

While this state of things is in a sense constituted by all individuals, it can be questioned by this same singularity by reappropriating the cum, namely, by transferring the concept of sharing to a global level. Jean-Luc Nancy expresses himself clearly when he connects the theme of plural singularity to globalization, linking both to the reflexive operations necessary to constitute a "good globalization":

One can attempt to think that this life, reduced to an absence of form other than its management motivated by an economic and social power that only seeks its maintenance, finds itself dialectically delivered to an absence of ends through which it would find itself as though in its nascent state, exposed to the absence of meaning of its bare contingency, such that it would be therefore capable of reclaiming as its own invention: an indefinite birth, sliding by its very errancy and by its absence of justification outside of the domination that manipulates it. The form of life would be the furtive play of an elegant withdrawal from the grinding machine. One can think on the contrary that the control thus revealed of a technological production of life places life in the state of producing itself as a whole, and of reappropriating the exteriority of domination in a common auto-production or auto-creation whose vitality reabsorbs and accomplishes, in itself, any politics. In one way or another, by an emphasis upon life itself or politics reappropriated in common, what is to put into play again is the twofold dialectical postulation by which, on the 
one hand, an extreme figure (previously known as the proletariat) is revealed - the bareness of which establishes its truth-character - while, on the other hand, the power reappropriated by the living community effectuates the negation of political separation. ${ }^{22}$

The solution, therefore, is not to reject the global and multi-ethnic dimension of society, but to turn this globality into something that constitutes the refitting of the cum, rendering the subject immediately "political": a participating actor on the global scene.

\section{Conclusion}

Throughout this paper, it has been shown that the aesthetic reflexivity contained in the philosophy of deconstruction can be the basis for a genuine concept of the global community. Challenging the interpretation of Scott Lash, who considers aesthetic reflexivity to be a form of non-reflexive adhesion of the "I" to the world, the argument has been made that an adherence of the subject to the structures that has reflexive characteristics can be located in the philosophy of Jean-Luc Nancy and Jacques Derrida. Starting from Nancy's reinterpretation of Heideggerian philosophy and following Derrida's critique of Husserl, it can be seen that reflexivity is fully present in deconstructionism. The necessary implication of the "I" in its objectifications does not involve the impossibility of questioning them analytically. The deconstructionist discourse seeks in this way to historicize the "I" while avoiding a connection with any community of belonging. In order to accomplish this, it uses the theoretical relationship that the "I" has with itself as a starting point. This leads to a subjectivity that is immediately plural and relational, and which reflexively maintains this state of plurality and relationality.

With these assumptions, deconstructionism is able to challenge the "communitarian" idea of an "I" that belongs to a specific community in a prereflexive way. Lash defines this condition of pre-reflexive sharing of signifiers as "hermeneutic reflexivity," referring to the work of Pierre Bourdieu. This paper argues instead that while his hermeneutic model saves the dimension of the communitarian bond, it completely loses that of the critical questioning of the community to which someone belongs. Therefore, the deconstructionist aesthetic model of reflexivity is the most suitable one for a scenario of ever increasing transnational interconnection, in which belonging to a historicalgeographic community is no longer a sufficient response to the challenges posed by global ethics.

22. Jean-Luc Nancy, The Creation of the World, Or, Globalization (Albany: State University of New York Press, 2007), 95. 


\section{Bibliography}

Beck, Ulrich, Anthony Giddens, and Scott Lash. Reflexive Modernization: Politics, Tradition and Aesthetics in the Modern Social Order. Stanford, California: Stanford University Press, 1994.

Bourdieu, Pierre. Distinction: A Social Critique of the Judgement of Taste. Cambridge, Massachusetts: Harvard University Press, 1984.

Derrida, Jacques. The Ends of Man, in Margins of philosophy. Chicago: The University of Chicago Press, 1984.

Derrida, Jacques. Edmund Husserl's "Origin of Geometry." University of Nebraska Press, 1989.

Derrida, Jacques. Voice and Phenomenon. Introduction to the Problem of the Sign in Husserl's Phenomenology. Northwestern University Press, 2011.

Heidegger, Martin, Joan Stambaugh, and Dennis J. Schmidt. Being and Time. Albany: State University of New York Press, 2010.

Husserl, Edmund. Logical Investigations. Translated by J.N. Findlay. London: Routledge, 1973.

Lacoue-Labarthe, Philippe, Jean-Luc Nancy, and Simon Sparks. Retreating the Political. London: Routledge, 1997.

Nancy, Jean-Luc. The Birth to Presence. Stanford, California: Stanford University Press, 1993.

Nancy, Jean-Luc. "Heidegger's 'Originary Ethics."' Studies in Practical Philosophy 1 no. 1 (1999).

Nancy, Jean-Luc. The Creation of the World, Or, Globalization. Albany: State University of New York Press, 2007. 